\title{
Note
}

\section{Changes in Abundance of Benthic Macroinvertebrates in a Pesticide-contaminated River}

\author{
Mitsuru TADA and Hiroaki SHIRAISHI
}

\begin{abstract}
Changes in benthic macroinvertebrates and concentrations of pesticide residues were surveyed at two stations in the Kajinashi River from April 1989 to September 1990 , focusing especially on the periods before and after transplantation of rice plants into paddy fields bordering the river. Fenobucarb (BPMC), butachlor and oxadiazon reached their peak concentrations $\left(4.6-12.5 \mu \mathrm{g} \cdot 1^{-1}\right.$ at upper site, $3.9-22.4 \mu \mathrm{g} \cdot 1^{-1}$ at lower site) soon or one month after rice transplantation. The other pesticides (e. g. fenitrothion, fenthion, chlornitrofen) were detected at peak concentrations below 1 $\mu \mathrm{g} \cdot 1^{-1}$ at each site. The density of Cheumatopsyche brevilineata (Trichoptera) larvae increased markedly, but larvae of Antocha sp. (Diptera) decreased after fenobucarb had reached its maximum concentration at the lower site. The $48-\mathrm{h} \mathrm{LC}_{50}$ values of insecticides and herbicides for the final instar larvae of both species were higher than those of concentrations detected in the river. However, Antocha sp. was more sensitive than $C$. brevilineata to fenthion $\left(48-\mathrm{h} \mathrm{LC}_{50}\right.$ values, 120 and $820 \mu \mathrm{g} \cdot 1^{-1}$, respectively).
\end{abstract}

Key words: pesticide contamination, benthic macroinvertebrate, Cheumatopsyche brevilineata, Antocha

Pesticides applied to rice paddies for pest control contaminate rivers (MARU, 1985; HANKAWA, 1985 ; COOPER et al., 1987 ; I WaKUMa et al., 1988a, 1993) and lakes (IMANAKA et al., 1985; Ono and Nakanisl, 1987 ; Shiraishi et al., 1988). This pesticide contamination causes severe damage to the invertebrate fauna of rivers, as reported in studies on pest control and faunal surveys in agricultural areas (MUIRHEAD-THOM. SON, 1987 ; IWAKUMA et al., 1988b). These studies have shown that some aquatic insects are more sensitive to pesticides than others. However, field observations of toxic effects on nontarget aquatic organisms have rarely been reported IWAKUMa et al., 1988b; Hatakeyama et al., 1990 ; TAKAMURA et al., 1991a, b).

In the present study, effects of pesticide contamination on benthic macroinvertebrates sensitive or insensitive to pesticides were inves- tigated throughout the year in the Kajinashi River, Ibaraki, Japan.

Study sites and methods. This study was carried out from April 1989 to September 1990 in the Kajinashi River. The river, located in the Kanto District of Japan, originates from a small pond $\left(1.6 \times 10^{-2} \mathrm{~km}^{2}\right)$ surrounded by rice fields in the town of Ogawa, Ibaraki Prefecture, and flows through an area of rice fields into Lake Kasumigaura. Two stations were selected along the course of the river; both were located among rice fields with a few scattered houses (Fig. 1). The stream width was about 3 $-4 \mathrm{~m}$, and was covered with gravel and sand at Sta. 1 (the upper site), and with clay and dead vegetation at Sta. 2 (the lower site).

Water temperature, specific conductivity and $\mathrm{pH}$ were measured with a portable conductivity meter and a $\mathrm{pH}$ meter (SC-51 and $\mathrm{PH}-81$, 


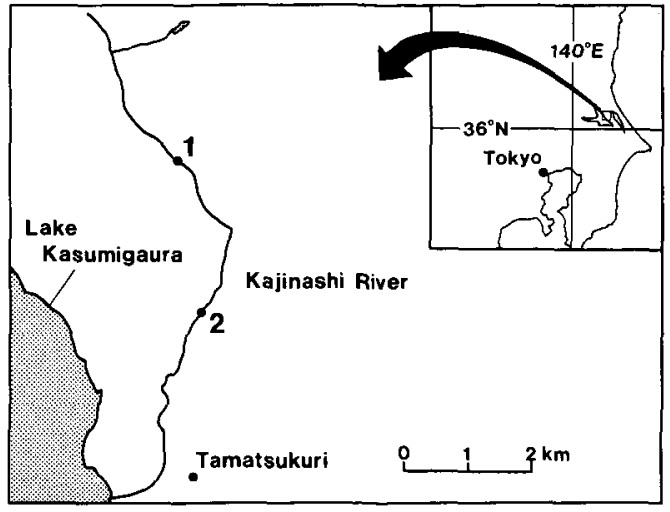

Fig. 1. Sampling sites in the R. Kajinashi flowing into Lake Kasumigaura.

Yokogawa Electric Works, Japan) between 10 : 00 and 11:00 at each site. A 500-ml water sample was collected at each site for pesticide analysis and brought back to the laboratory in an ice chest.

According to the methods of IwaKuma et al. (1988a) and TAKAMUrA et al. (1991a), the water was filtered through a Whatman GF/C glass fiber filter and passed through an ODS tube (Bond Elute C18, Analytichem International, U. S.A.), which was then centrifuged with acetone to extract the pesticides. Pesticide concentrations in the extracts were analyzed by gas chromatography using ECD and NPD detectors (Model 5890A, Hewlett Packard, U.S.A.).

Three samples of benthic macroinvertebrates were collected with a Surber box sampler (Rigosha, Japan) with a 0.3-mm mesh net from riffles at each site monthly (three times a month from May to July) from April 1989 to September 1990 . The sampler covered a $25 \mathrm{~cm} \times 25 \mathrm{~cm}$ area of the river bottom. Animals in the samples were preserved in $10 \%$ formalin, and aquatic insects were later hand-sorted in the laboratory, and identified by family, genus, or species if possible, under a binocular microscope ( $\times 10-64$ magnification) using keys recommended by KaWAI (1990).

D-frame net (Rigosha, Japan) samples composed of the dominant species, Cheumatopsyche brevilineata (Trichoptera, Hydropsychidae) and Antocha sp. (Diptera, Tipulidae) were collected at Sta. 2 in May 1990. The specimens were brought back alive to the laboratory and used immediately for acute toxicity testing as described below.

The $48-\mathrm{h} \mathrm{LC}_{50}$ values of four kinds of pesticides, fenobucarb (BPMC), fenthion, oxadiazon and chlornitrofen were calculated by Finney's probit analysis method (FINNEY, 1971) for the larvae of $C$. brevilineata and Antocha sp.. The test was conducted using 4 replicate $100-\mathrm{ml}$ glass beakers containing $50 \mathrm{ml}$ of test water and 5 individuals each of the final instar larva of $C$. brevilineata and Antocha sp. in a static condition. They were maintained in the laboratory at a temperature of $15 \pm 1^{\circ} \mathrm{C}$ under a $12-\mathrm{h}$ light cycle using fluorescent lights.

Physicochemical features. The water temperature stayed relatively constant, varying little from May to August at each site (19.8$24.5^{\circ} \mathrm{C}$ at Sta. $1,16.9-22.6$ at Sta. 2). The $\mathrm{pH}$, ranging from 7.0 to 8.0 , stayed fairly constant at each site. Specific conductivity at Sta. 1 (245$360 \mu \mathrm{S} \cdot \mathrm{cm}^{-1}$ ) was always higher than at Sta. 2 $\left(137-288 \mu \mathrm{S} \cdot \mathrm{cm}^{-1}\right)$, because of point sources of sewage in the watershed from the dwellings around Sta. 1.

Concentrations of pesticide residues. Three insecticides (fenobucarb, fenitrothion, fenthion), four herbicides (butachlor, oxadiazon, simetryn, chlornitrofen) and a fungicide (iprobenfos) were detected in the river water. Four pesticides were detected at appreciable concentrations and for various durations (Fig. 2). The other pesticides were detected at peak concentrations below $1 \mu \mathrm{g} \cdot 1^{-1}$ at each site. Fenobucarb (insecticide) was detected on 16 May 1989 at Sta. 1 with a maximum concentration of 12.5 $\mu \mathrm{g} \cdot 1^{-1}$ and on 15 June 1989 at Sta. 2 with a maximum concentration of $22.4 \mu \mathrm{g} \cdot 1^{-1}$. With regard to other pesticides, the herbicides butachlor at Sta. 2, and oxadiazon at Sta. 1, were detected at maximum concentrations above 10 $\mu \mathrm{g} \cdot 1^{-1}$ just after transplantation of rice plants in May of 1989 and 1990. Simetryn was detected with a small peak at each site from June to July 1989 and 1990.

Changes in density of macroinvertebrates. Collection of aquatic insect larvae from the stations in the Kajinashi yielded 13 taxa and 
five orders, listed in Table 1. Many of these species were collected sporadically, except for Baetis sahoensis (Ephemeroptera, Baetidae), $C$.

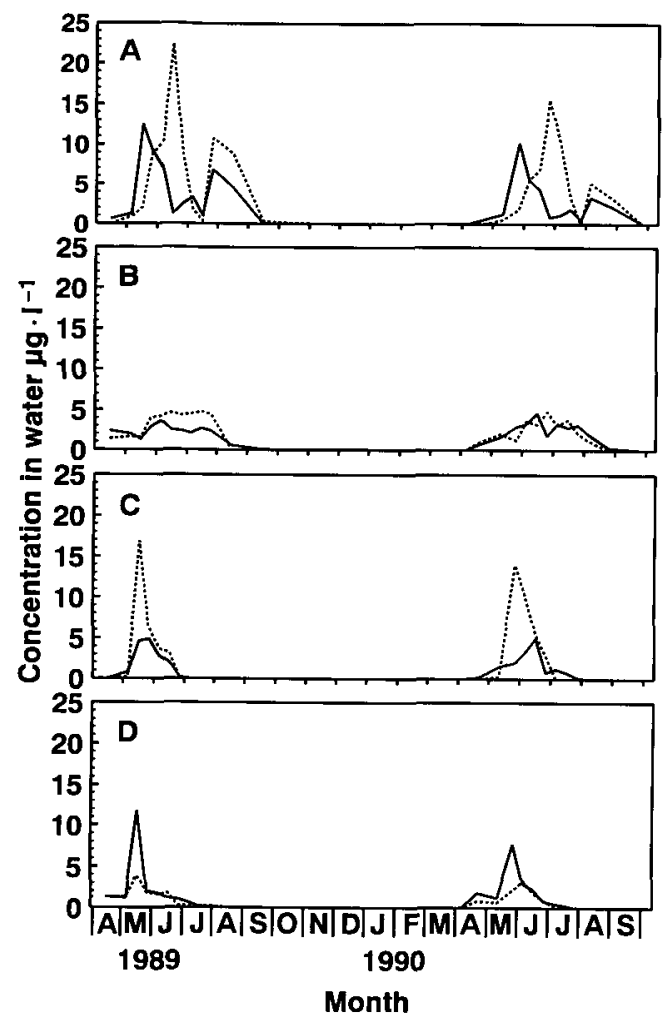

Fig. 2. Concentrations of four pesticides in water collected from two stations in the $\mathrm{R}$. Kajinashi. A, fenobucarb; B, simetryn ; C, butachlor; D, oxadiazon, - $\longrightarrow$ Sta. 1; -...-., Sta. 2. brevilineata and Antocha sp.. For comparison between different sites and dates, species distributed ubiquitously are preferable. B. sahoen-

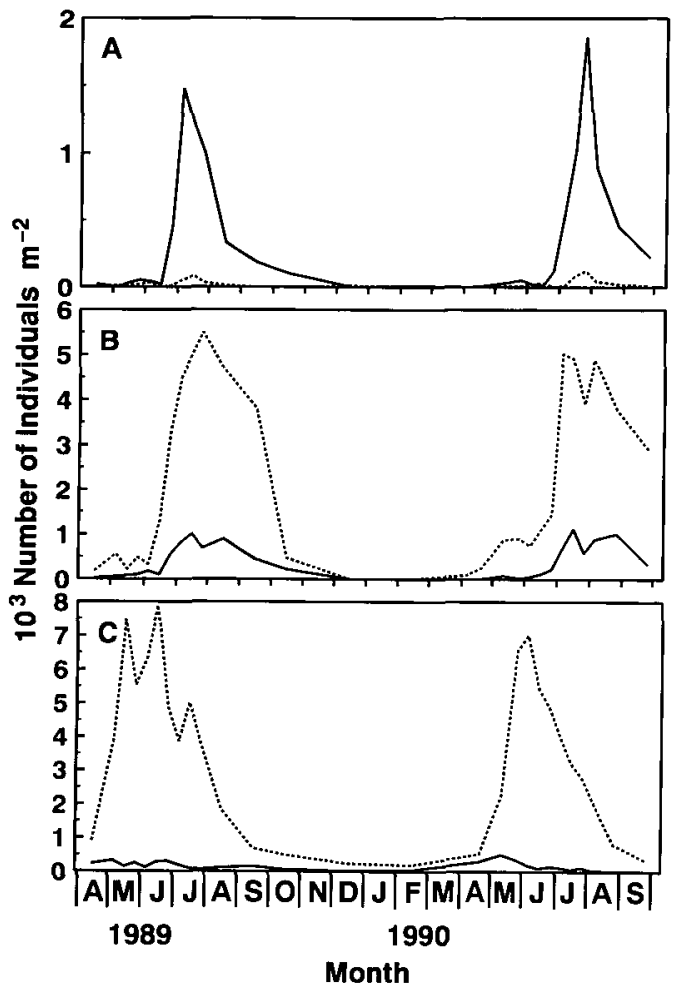

Fig. 3. Density of three aquatic insects at two stations in the R. Kajinashi. A, Baetis sahoensis ; B, Cheumatopsyche brevilineata ; C, Antocha sp. —, Sta. 1 ; -...-, Sta. 2.

Table 1. Taxa of benthic macroinvertebrates collected in the R. Kajinashi.

Ephemeroptera

Baetis sahoensis

B. thermicus

B. sp. $\mathrm{H}$

Ephemera japonica

Drunella sp.

Odonata

Anotogaster sieboldii
Trichoptera

Cheumatopsyche brevilineata

Rhyacophila sp.

Hydroptila sp.

Diptera

Antocha sp.

Chironomidae

Plecoptera

Nemoura sp.

Taniopterygidae 
sis, C. brevilineata and Antocha sp. met this criterion.

Changes in density of these three species are shown in Figure 3. The larvae of $B$. sahoensis increased at Sta. 1 from June to July (maximum density of three samples: 1,480 individuals $\mathrm{m}^{-2}$ on 4 July 1989 and 1,860 on 25 July 1990 ), although their numbers remained low just after pesticide application at each site (when fenobucarb, butachlor and oxadiazon reached their peak concentration at Sta. 2). Few individuals of this species were seen at Sta. 2 even in July 1989 and 1990 . The small numbers of $B$. sahoensis at each site from May to June suggested that this species was sensitive to insecticide contamination, as reported by IWAKUмa $e t$ al. (1988b).

The larvae of $C$. brevilineata showed a marked increase at Sta. 2 from June to July of 1989 and 1990, just after pesticide application. The density was very high, exceeding 5,000 individuals $\mathrm{m}^{-2}$, between July and August. IwaKuma et al. (1988b) reported that the density of this species was adversely affected by fenobucarb contamination after pesticide appli. cation. However, this trichopteran species continued to increase after fenobucarb had reached its maximum concentration at Sta. 2. Therefore it is possible that this species was not damaged by pesticide contamination at this station during our study.

The larvae of Antocha sp. showed a marked increase at Sta. 2 but remained small in numbers at Sta. 1 from May to June of 1989 and 1990. The density of this dipteran species decreased from 7,890 individuals $\mathrm{m}^{-2}$ on 15 June to 3,860 on 5 July 1989 after fenobucarb had reached its maximum concentration at Sta. 2.

No pesticides were detected from December 1989 to March 1990, but the density of the larvae of the three species remained very low at each site. Therefore, it is possible that life cycle events such as recruitment, drift and emergence may have an influence on species density.

The $\mathrm{LC}_{50}$ values of pesticides for $C$. brevilineata and Antocha sp. Table 2 shows that the $48-\mathrm{h} \mathrm{LC}_{50}$ values of fenobucarb, fen-
Table 2. The $48-\mathrm{h} \mathrm{LC}_{50}$ values $\left(\mu \mathrm{g} \cdot 1^{-1}\right)$ of four pesticides for Cheumatopsy. che brevilineata and Antocha sp..

\begin{tabular}{lcc}
\hline & $\begin{array}{c}\text { Cheumatopsyche } \\
\text { brevilineata }\end{array}$ & Antocha sp. \\
\hline fenobucarb & 700 & 810 \\
fenthion & 820 & 120 \\
oxadiazon & 9,000 & 9,400 \\
chlornitrofen & 12,400 & 8,900 \\
\hline
\end{tabular}

thion, oxadiazon and chlornitrofen for the final instar larvae of C. brevilineata and Antocha sp. were higher than those of concentrations detected in the river, especially those of the herbicide oxadiazon. Neither species was sensitive to herbicide or insecticide in the acute toxicity test, but Antocha sp. was more sensitive than $C$. brevilineata to fenthion $\left(48-\mathrm{h} \mathrm{LC}_{50}\right.$ values, 120 and $820 \mu \mathrm{g} \cdot 1^{-1}$, respectively).

$B$. sahoensis tends to be susceptible to pesticides within a day under static conditions because it normally lives under conditions of flow. Thus it is difficult to conduct the same bioassay on species under identical conditions.

Discussion. Several kinds of pesticides contaminate river water from rice fields, and their concentrations are at acutely sublethal levels as TAKAMURA et al. (1991a) discussed and the present study confirms. However, as the contamination continues for more than a month, it can damage macroinvertebrates (IWAKuma et $a l ., 1988 \mathrm{a}, \mathrm{b})$. In the present study, fenitrothion, fenthion and chlornitrofen were also detected at concentrations lower than their peak concentration of $1 \mu \mathrm{g} \cdot 1^{-1}$ in the river. However, MarU (1985) reported that fenthion was detected with a maximum concentration of $14.6 \mu \mathrm{g} \cdot 1^{-1}$ in water within Chiba Prefecture, and that its concentration rapidly decreased. These results suggest that insecticides and other pesticides besides fenobucarb may cause changes in Antocha sp. larval density through joint or synergistic effects in river water.

In addition to pesticide contamination, food habitats and life-cycle events could exert some influence on the changes in density of the three species at each site (Fig. 3). More field experiments using a flowing system (e.g. Yasuno et 
al., 1985; TaKamura, 1992, 1993) and bioassay for pesticide toxicity to $B$. sahoensis, $C$. brevilineata and Antocha sp. are needed to evaluate the sublethal effects of contamination $\left(\mathrm{LC}_{50}\right)$ by pesticides individually and in combination on ecology or behavior. In addition, further studies are needed of acutely lethal levels, as reviewed by НаSнiмото (1982) and described above.

\section{Acknowledgements}

We acknowledge the valuable advice given by Dr. S. Hatakeyama of the National Institute for Environmental Studies. We are grateful to Mr. N. Kobayashi, Asahi Technical Institute, who identified some of the aquatic insect specimens, and to Dr. K. TANIDA, University of Osaka Prefecture, for his helpful advice on the taxonomy of $C$. brevilineata.

\section{摘 要}

\section{残留農薬の検出される河川での底生動物の変動}

茨城県の梶無川の 2 地点において 1989 年 4 月 から 1990 年 9 月にかけて農薬の施用される田植 えの前後を中心に, 残留農薬度と底生動物の個体 数密度の調査を行った。各地点で田植え後から一 カ月の間で BPMC (殺虫片), ブタクロールとオキ サジアゾン (以上, 除草剤)の水中濃度が高くなっ た（上流の地点で 4.6-12.5 $\mu \mathrm{g} \cdot 1^{-1}$, 下流の地点 で3.9-22.4 $\left.\mu \mathrm{g} \cdot 1^{-1}\right)$ 。フェニトロチオ，フェ ンチオン（以上，殺虫剤）やクロルニトロフェン (除草剤) などその他の農薬では, 最高で $1 \mu \mathrm{g}$. $1^{-1}$ 以下であった。下流の地点で BPMC の水中濃 度が最高に達してからも，コガタシマトビケラ幼 虫の密度は急速に増大したが, Antocha sp. 幼虫 の密度は減少した。両種の終令幼虫で殺虫㓮と除 草剂と $\mathrm{LC}_{50}$ (48 時間) を調べると, それぞれ野外 で検出される濃度に比べて高い值であった。フェ ンチオンについては, Antocha sp. 幼虫はコガタ シマトビケラに比べて感受性が高かった。

\section{References}

Cooper, C. M., F. E. Dendy, J. R. Mchenry and J. C. Ritchie (1987): Residual pesticide concentrations in Bear Creek, Mississippi, 1976 to 1979. J. Environ. Qual., 16:69-72.

Finney, D. J. (1971): Probit Analysis. Cambridge
Univ. Press, Cambridge.

HANKAWA, Y. (1985) : Behavior of molinate in paddy and river water. J. Pesticide Sci., 10:107-112 (in Japanese with English abstract).

Hashimoto, Y. (1982): Effects of pesticides on aquatic organisms and their environment. J. Pesticide Sci., 7 : 281-287.

Hatakeyama, S., H. Shiraishi and N. Kobayashi (1990) : Effects of aerial spraying of insecticides on nontarget macrobenthos in a mountain stream. Ecotoxicol. Environ. Saf., 19: 254 -270 .

Imanaka, M., S. Hino, K. Matsunaga and T. Ishida (1985): Oxadiazon residues in surface water and crucian carp (Carassius Cuvieri) of Lake Kojima. J. Pesticide Sci., 10: 125-134.

Imakuma, T., K. Takamura, S. Nohara and K. Ta. KAMURA (1988a): Pesticide residues in water and sediment of the River Koise and its tributaries. Res. Rep. Natl. Inst. Environ. Stud. Jpn., 114 : 73-83 (in Japanese with English abstract).

Imakuma, T., K. Takamura and S. Nohara (1988b) : Dynamics of benthic communities in tributaries of the River Koise in relation to residual pesticides. Res. Rep. Natl. Inst. Environ. Stud. Jpn., 114: 85-100 (in Japanese with English abstract).

Iwakuma, T., H. Shiraishi, S. Nohara and K. Ta. KAMURA (1993): Runoff properties and change in concentrations of agricultural pesticides in a river system during a rice cultivation period. Chemosphere, $27: 677-691$.

Kawal, T. (1990): An Illustrated Book of Aquatic Insects of Japan-4th ed. Tokai Univ. Press, Tokyo (in Japanese).

Maru, S. (1985) : Monitoring survey of pesticides in river water within Chiba Prefecture. Ecol. Chem., 8: 3-10 (in Japanese).

Muirhead-Thomson, R. C. (1987) : Pesticide Impact on Stream Fauna with Special Reference to Macroinvertebrates. Cambridge Univ. Press, Cambridge.

Ono, H. and J. Nakanisi (1987): Herbicide, CNP contamination in the lake Kasumigaura basin. Water Res., 21: 669-675.

Shiraishi, H., F. Pula, A. Otsuki and T. Iwakuma (1988): Behavior of pesticides in lake Kasumigaura, Japan. Sci. Total Environ., 72 : $29-42$.

Takamura, K., S. Nohara, T. Kariya, M. Okazaki and K. ITO (1991a) : Effects of pesticide contamination from rice fields on stream benthic arthropods. Jpn. J. Limnol., 52 : 95-103. 
Takamura, K., S. Hatakeyama and H. Shiraishi (1991b): Odonate larvae as an indicator of pesticide contamination. Appl. Ent. Zool., 26 : 321-326.

Takamura, K. (1992) : Decrease of chironomid emergence by exposure to the surfactant $\mathrm{ABS}$ in artificial channels. Jpn. J. Limnol., $53: 363$ -372 .

TAKamura, K. (1993): Population changes among chironomid species related to secondary effects of pesticide application in rice fields. Arch. Hydrobiol., 127 : 205-225.

Yasuno, M., Y. Sugaya and T. Iwakuma (1985):
Effects of insecticides on the benthic community in a model stream. Environ. Pollut., 38 : $31-43$.

(著者：多田 満, 国立環境研究所生物圈環境部； 白石寞明, 国立環境研究所地域謤境研究グループ、テ 305 茨城県つくば市小野川 16-2 ; Mitsuru TADA, Hir oaki Shiraishi, National Institute for Environmental Studies, Onogawa, Tsukuba 305, Ibaraki)

Received : 5 October 1993

Accepted : 26 January 1994 